Papers and Proceedings of the Royal Society of Tasmania, Volume 117, 1983.

(ms. received 24.11 .1982$)$

\title{
BIRDS IN TASMANIAN PINE PLANTATIONS
}

by L.E. Wa11

63 E1phinstone Road, North Hobart, Tasmania

(with two tables)

ABSTRAC'T

WALL, L.E., 1983 (31 viii) :Birds in Tasmanian pine plantations. Pap. Proc. R. Soc.Tasm., 117: 125-133. https://doi.org/10.26749/rstpp.117.125 ISSN 0080-4703.

63 Elphinstone Road, North Hobart, Tasmania.

The number of bird species in Pinus radiata plantations aged between 8 and 31 years and in native forests in Tasmania during a year is recorded.

The oldest plantations had a slightly greater number of species than the younger ones because after thinning of the pines there was some regeneration of ground cover which provided another habitat. Most species, however, fed chiefly on the trunks and foliage of the pines. The number of species was greater in the native forests and was consistent in the five plots surveyed. Only one species was found nesting in the pine plots.

\section{INTRODUCTION}

Exotic pines, principally Monterey pines, have been cultivated as a source of mil1able timber and for pulpwood in Australia in increasing numbers during the last forty years. During this time there has been growing concern that these plantations have been replacing native forests to the detriment of the native fauna and flora.

Several studies have been undertaken in other Australian States to ascertain the extent of this problem, e.g. Pawsey (1966), d'Andria (1968), Cowley (1971), Kloeden (1973), Gepp \& Fife (1975), Suckling et al. (1976), Davidson (1976), Disney \& Stokes (1976), Gepp (1976), Driscoll (1977), and Friend (1982), and one brief study in Tasmania by Fielding (1976). In most of these the study plots were many hectares in area and contained watercourses, firebreaks and native vegetation so that the results might not be truly representative of bird populations in pure pine plantations.

My study was undertaken to assess the numbers of bird species in pine plantations not affected by other influences, and to compare these with the birdlife in adjacent native forests.

\section{METHODS}

Six plots in Monterey pine plantations and five study plots in adjacent native forests were selected for study. Five of the pine plots were $200 \mathrm{~m}^{2}$ ( 4 ha in area) and the sixth was a triangular plot 4.9 ha in area. In all plots the canopy was closed but the ages of the trees varied from 8 to 31 years, and the amount of thinning and pruning varied also. To overcome any local bias three plots of different ages were chosen in the Burnie district of northwestern Tasmania and three plots of approximately the same ages in the Scottsdale district in northeastern Tasmania.

Whenever feasible, observations in each plot were alternated between morning and afternoon. Plots were chosen free from native vegetation wherever possible, and creeks, roadsides and other influences excluded. Each observation plot was a small part of a much larger plantation. Further details about each plot are given below. 
Monthly visits were made to each plot and one hour spent in recording all birds seen or heard. Another period of observations, not exceeding one hour, was spent in nearby native forest. By extending the study for a full year, from August 1981 to July 1982, any seasonal fluctuations were recorded. The usual routine for each visit was to traverse the boundaries of the plot and then to criss-cross it at random.

Common names of birds are those recommended in "The Emu", vol.77 supplement, May 1978. For ferns I have used the common names from N.A. Wakefield's "Ferns of Victoria and Tasmania", 1955; for fungi. I have used the common names from Macdonald \& Westerman's "A Field Guide to Fungi of South-eastern Australia", 1979; and for other plants I have followed "The Student's Flora of Tasmania" by W.M. Curtis, 1956-1967.

\section{PLOT DESCRIPTIONS}

1. Kamona, near Scottsdale (part of Forestry Comnission Compartment 4)

Planted 1950 , at spacing $2.4 \times 2.4 \mathrm{~m}$ (i.e. $8 \times 8$ feet)

1st pruning $1957-8$ to $2 \mathrm{~m}$

$1959-60$ to $6.4 \mathrm{~m}$

On a gentle slope facing west; altitude about $100 \mathrm{~m}$.

Soil - yellow podzols on granite.

As a result of thinning there is a good penetration of sunlight on this plot resulting in about $80 \%$ ground cover of austral king-fern, austral bracken and other ground ferns, with scattered dogwood, fireweed, native currant and seedling pines up to $2 \mathrm{~m}$ high. In the autumn there is substantial growth of the introduced fly agaric.

The wet sclerophyl1 forest used as a control is immediately west of compartment 4. It is dominated by swamp gum, and blackwood with dogwood understorey and ground cover of austral bracken and other ferns.

2. Cuckoo, near Scottsdale (part of Forestry Commission Compartment 9)

Planted 1954, at spacing $2.4 \times 2.4 \mathrm{~m}$.

Pruned 1962-63 1st thinned 1977-78

On a steep slope facing south; altitude about $250 \mathrm{~m}$.

Soil - yellow podzols on granite.

The ground cover is very sparse - occasional soft treeferns and very few austral bracken stems. Fly agaric is very common in autumn.

The wet sclerophyli rainforest used as a control is nearby on the east side, with a creek runing through it. It is dominated by swamp gum, blackwood and myrtle with understorey of dogwood and musk and ground cover of ferns.

3. Cuckoo, near Scottsdale (part of Forestry Commission Compartment 37)

Planted 1966 , at spacing $2.7 \times 2.7 \mathrm{~m}$.

Unthinned and unpruned.

On a medium slope facing north; altitude about $200 \mathrm{~m}$.

Soil - yellow podzols on granite.

There is extensive die-back of needles on lower branches. A few dogwoods occur in the lower section of the plot. A gravel road runs diagonally through this plot but there is no roadside vegetation and the canopy remains closed.

A wet sclerophyll forest on the southeastern side is used as a control. It is dominated by swamp gum and stringybark, blackwood and silver wattle, with an understorey of dogwood and musk and a ground cover of ferns. 


\section{L.E. Wall}

4. O1dina, near Burnie (part of Forestry Commission Compartment 54A)

Planted 1952, at spacing $2.4 \times 2.4 \mathrm{~m}$.

lst pruning to $2.4 \mathrm{~m} \quad 1.959$

2nd pruning to $4.9 \mathrm{~m} \quad 1960$

3rd pruning to $6.7 \mathrm{~m} 1962$

On a gentle slope facing west, altitude about $80 \mathrm{~m}$.

Soil - clay of basaltic origin.

A sparse ground cover of mother shield-fern, austral bracken, saggs and low blackberry vines. In autumn there are considerable amounts of fungi, principally fly agaric and saffron milk cap.

A wet sclerophyll/rainforest around a small grassed picnic ground $2 \mathrm{~km}$ south was used as a control. A small creek flows through it. It is dominated by stringybark and manna gum, blackwood and a few myrtles. The understorey is composed of silver wattle and cheesewood, with ground cover of austral bracken, other ferns and blackberries (very profusely).

5. East Ridgley, near Burnie (part of Associated Forest Holdings plantation)

Planted 1969 at spacing $3 \times 2 \mathrm{~m}$.

Thinned by removing each third row in 1981; unpruned.

Soil - clay of basaltic origin; altitude about $250 \mathrm{~m}$.

A triangular plot, very steep in part but mostly gently sloping to the west.

There was some wind damage because this plot takes the full force of the prevailing winds. Much trash from the thinning operations remains on the ground. There was a strong growth of grass and thistles where rows of trees had been removed, and very few austral bracken stems and fireweed. In the autumn a moderate number of fungi, mostly fly agaric, was in evidence.

In February, cattle from the neighbouring farm were feeding on the grass but not on the thistles. In March, the cattle had been removed and the thistles were seeding heavily, but there was no indication that they were attracting birds.

This plantation is surrounded by grazing lands with no native forests in the vicinity to be used as a control. The plantation was chosen because the thinning differs from Forestry Commission practice but there is no evidence that the different practices have any effect on the birdlife.

6. West Ridgley, near Burnie (part of Associated Forest Holdings plantation)

Planted 1973, with spacing $3 \times 2 \mathrm{~m}$.

Unthinned and unpruned; extensive needle dieback on lower branches.

A level plot except for a slight fall near the western boundary.

Soil - clay of basaltic origin; altitude about $260 \mathrm{~m}$.

A road skirts the eastern boundary with blackberries on the verge. A small depression within the plot is encircled by blackberries and sometimes contains water, and near the western boundary are a few straggling dogwoods and silver wattle saplings.

Just to the east of this plot is a similar area of wet sclerophyll forest used as a control. It is dominated by stringybark and blackwood, with an understorey of cheesewood and mountain pepper and a ground cover of blackberries, austral bracken and other ferns. 
RESULTS

In Plot 1 six species were seen on at least five visits: ranked in order of number of visits on which each was sighted they were - grey shrike-thrush (12), Tasmanian thornbill (11), green rosella (10), superb fairy-wren (10), white-browed scrubwren (9), dusky robis $(6)$.

In contrast, nine species were seen on at least five visits to the native forest: ranked in order of the number of visits on which each was seen these were - grey fantail (11), green rosella (11), forest raven (10), Tasmanian thornbil1 (10), grey shrike-thrush (8), blackbird (7), pink robin (6), laughing kookaburra (5), grey currawong (5).

A total of 28 species was recorded in native forest and 18 in pines.

In Plot 2 only one species, grey shrike-thrush, was recorded on at least five visits to the pines; it was seen on eight visits. On three visits no birds were seen.

In the native forest eight species were seen on at least five visits: ranked in order of the number of visits on which each was seen these were - grey shrike-thrush (11), Tasmanian thornbill (11), grey fantail (9), golden whistler (7), silvereye (7), green rosella (6), white-browed scrubwren (6), forest raven (5).

A total of 22 species was recorded in native forest and 12 in pines.

In Plot 3 only two species - Tasmanian thornbill (8) and White's thrush (5) - were recorded on at least five visits to the pines.

In the native forest 12 species were recorded on at least five visits: in order of the number of visits on which each was seen they were - grey shrike-thrush (10), grey fantail (10), Tasmanian thornbil1 (9), white-browed scrubwren (9), green rosella (8), blackbird (7), superb fairy-wren (7), forest raven (7), strong-billed honeyeater (6), golden whistler (5), eastern spinebill (5), silvereye (5).

A total of 26 species were recorded in native forest and 14 in pines.

In Plot 4 five species were recorded on at least five visits to the pines: in order of the number of visits on which each was seen they were - forest raven (7), grey shrikethrush (7), blackbird (6), Tasmanian thornbill (6), dusky robin (5). In the native forest seven species were recorded on at least five of ten visits: in order of the number of visits on which each was seen they were - Tasmanian thornbil1 (9), golden whistler (8), grey shrike-thrush (8), grey fantail (8), superb fairy-wren (8), green rosella (7), forest raven $(6)$.

A total of 27 species was recorded in native forest and 14 in pines.

In Plot 5 three species were recorded on five or more visits: in order of number of visits on which each was seen they were - grey shrike-thrush (9), Tasmanian thornbil1 (7), green rosella (5). purposes.

As indicated earlier there was no native forest adjacent to this plot for comparative

A total of 14 species was recorded in this plot. visits.

In Plot 6 only one species, Tasmanian thornbill (7), was recorded on at least five

Eight species were recorded in the native forest on at least five visits: in order of the number of visits on which each was seen they were - grey fantail (10), Tasmanian 


\section{L.E. Wall}

thornbil1 (1), blackbird (9), superb fairy-wren (9), green rosel1a (8), grey shrikethrush (8), forest raven (8), white-browed scrubwren (7).

A total of 24 species was recorded in native forest and 11 species in pines.

Table 1 summarises the sightings in a11 plots.

TABLE 1

COMPARISON OF THE NLMBER OF BIRD SPECIES

recorled in pine plots and native forests (bracketed numbers) in Tasmania. Number of visits on which each species was recorded.

$\begin{array}{lllllll}\text { species } & \text { Plot } 1 & \text { Plot } 2 & \text { Plot } 3 & \text { Plot } 4 & \text { Plot } 5 & \text { Plot } 6\end{array}$

Brown goshawk

Peregrine falcon

Plot 1

Plot 2 plot 3 plot 4

Brown falcon

(1)

Swamp quail

Tasmanian native-hen

(1)

Brush bronzeing

Yellow-tailed black-cockatoo

Green rosella

Fan-tailed cickoo

Shining bronze-cuckoo

Laughing kookaburra

Welcome swallow

B1ack-faced cuckoo-shrike

White's thrush

Blackbird

Pink robin

Flame robin

Scarlet robin

Dusky robin

Olive whist ler

Golden whistler

Grey shrike-thrush

Satin flycatcher

Grey fantail

Superb fairy-wren

White-browed scrubwren

Scrubtit

Brown thornbill

Tasmanian thornbill

Yellow-throated honeyeater

Strong-billed honeyeater

Black-headed honeyeater

Crescent honeyeater

Eastern spinebill

Striated pardalote

Silvereye

(4)

$$
\text { (1) }
$$

(2)

10 (11) $3(6)$

4 (4)

(1)

(2)

2 (5)

(2)

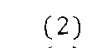

(3)

$4(7)$

2 (6)

2 (3)

6 (2)

$\begin{array}{ll}6 & (2) \\ 3 & (4)\end{array}$

(3)

12 (8)$$
\text { (7) }
$$

4 (11)

10 (3)

9 (3)

8 (11)

1

3 (8)

3 (7)

(2) 1 (2)

(1)

1 (1)

1

5 (1) 1 (2)

4 (7)

1 (2)

2 (1)

(3)

(2)

1 (1)

2 (1)

1

5 (3)

2 (1)

$$
\text { (5) }
$$

(8)

3 (10)

7 (8)

(1)

$$
\text { (9) }
$$

(2)

(6)

$2(10)$

1 (8)

(7) $3(8)$

1 (9)

(2)

(1)

4

11 (10)

(10) 4 (11)

(1)

(3)

8 (9)

$6(9)$

(3)

(4)

(6)

(1)

3 (4)

(2)

(5)

(1)

3 (5)

1 (2)

(1)

Common starling

Grey butcherbird

Black currawong

Grey currawong

Forest raven

1 (5)

1 (2)

(10) $\quad 1$ (2)

(2)

(3)

1 (7)

7 (6)

4
11 (24)

1 4 (9)

2 (10)

1 (9)

$3(7)$

(10)

(2)

14 (26)

$14 .(27)$

14 


\section{DISCUSSION}

Pawsey (1966) compared the bird populations of pine forests in southeastern South Australia in 1950 and 1965 and concluded that the number of species in closed canopy forests, including firebreaks, had increased almost fivefold in that period. He presumed that increased insect life had caused the increase. It is not possible to relate this to my observations because Pawsey gave insufficient data on tree spacing and his study plots included firebreaks and clearings of unknown extent. Further, there had been no thinning of the pines before 1950 and the extent of subsequent thinning, which could have allowed extensive growth of ground cover, is unknown to me.

Thirteen species were recorded in a very brief survey of Majura forest pine plantation, aged forty years, near Canberra, by d'Andria (1968), but these results are not comparable with mine because in the Canberra plot there was no undergrowth and the spacing of trees and the extent of thinning was not stated. Davidson (1976) referred to this forest and stated that some had been pruned and thinned and there were a few creeks but this does not specifically refer to the same part as that surveyed by d'Andria.

Cowley (1971) gave a summary of the relationship between birds and forests. He referred to a survey undertaken in pine plantations in Creswick, Victoria, but this was restricted to mature pines and the extent of thinning and presence of native undergrowth was not shown so that a comparison with my study must be imprecise. Cowley showed that the number of bird species in pines was only $52 \%$ of those in eucalypt forest (whether wet or dry sclerophyll was not stated) and this accords with my results in Tasmania.

In 1972 at Silver Creek, Victoria, Kloeden (1973) reported that 47 species were observed in native forest and 42 species in pine plots, and at Longford, Victoria, 52 species in native forests and 37 species in pine plots. These results do not provide a satisfactory comparison because although the pine plots were of varying ages the results were combined and the extent of thinnings, if any, were not given.

Gepp \& Fife (1975) recorded the number of bird species in pine plantations of varying age and structure and in native forest in South Australia in 1974. The age and extent of thinning in these pine plots seemed similar to those in my study plots. Comparative results are shown in table 2. They indicate that each of the South Australian plots had many more species than those in Tasmania but this is predictable because Tasmania has a paucity of species (Ridpath \& Moreau 1966). In South Australia and in Tasmania the native forests had more than double the numbers of birds species present than were present in pine forests, but the proportions of the species seen frequently in all the South Australian pine plots were greater than in Tasmania. However, the native forests in Tasmania had a greater proportion of species seen frequently than in South Australia.

\section{TABLE 2}

COMPARISON OF THE NUMBER OF BIRD. SPECIES recorded in pine plots and native forest

in South Australia and Tasmania.

\begin{tabular}{lcccccc} 
& $\begin{array}{c}\text { Total number } \\
\text { of species }\end{array}$ & $\begin{array}{c}\text { Number of } \\
\text { frequent1y seen } \\
\text { species }\end{array}$ & \multicolumn{2}{c}{$\begin{array}{c}\text { Percentage of } \\
\text { frequently seen } \\
\text { species }\end{array}$} \\
& S.A. & Tasm. & S.A. & Tasm. & S.A. & Tasm. \\
Unthinned & 32 & 17 & 17 & 2 & 53 & 12 \\
Middle-aged (thinned) & 35 & 18 & 18 & 4 & 51 & 22 \\
Old & 39 & 13 & 18 & 4 & 49 & 31 \\
Native forest & 78 & 43 & 15 & 15 & 19 & 35
\end{tabular}


L.E. Wa 11

There do not appear to be clear reasons for these differences. It should be noted that the South Australian survey was in dry sclerophyll forest whereas my study was in wet sclerophyl1. Disney \& Stokes (1976) stated that wet sclerophyll forests in New South Wales contained a greater diversity of bird species than dry sclerophyll forests but this does not apply in Tasmania (Ratkowsky \& Ratkowsky 1978, 1980).

A survey in northeastern Victoria in pine plantations of varying ages and in mature eucalypt forest was carried out by Suckling et al. (1976). This is not comparable with my study because of the inclusion in the Victorian plots of creek-side vegetation over large areas, and lack of knowledge of the extent of thinning.

Davidson (1976) reported on a brief survey carried out in Kowen Forest, in the Australian Capital Territory, during a nine-week period in summer. The plots used were comparable in ages to those used here but they were much 1 arger and in all cases contained watercourses with native vegetation along them. Davidson's comments on species common to both his and my studies agree with my experience in some cases but are opposed in others. He quoted brown thornbills as common in all plots and as feeding at all heights: I agree if Tasmanian and brown thornbills (very similar species with a considerable overlap of habitat) are treated together. Davidson found that grey fantails occurred only among native trees: that was not true in my study, nor was his finding that the grey shrikethrush was less common in the older pine plantations. He also reported that silvereyes foraged high in the trees as well as in the undergrowth in all pine plots but were uncommon in native forests: in my study they were seen only occasionally in pines but were frequently seen in all native forests.

A study in Bathurst district of New South Wales in one plot of wet sclerophyl forest, one plot of dry sclerophyll forest and one plot of 18 year old pines was reported by Disney \& Stokes (1976). They listed only those species of birds found breeding and it was not stated that nesting was confined to the pines; it is probable that some species nested in trees and undergrowth along watercourses which occurred within the pine plot. Gepp (1976) reported on a study in an exotic forest in South Australia, emphasising the difference in the number of sightings at the edge of plots compared to those well inside the plots. This difference is most noticeable in unthinned and middle-aged pines. In this study care was taken to exclude edges of plantations to avoid such influences.

Fielding (1976) reported on brief visits to a number of pine plantations of varying ages in several districts of Tasmania. His findings are not inconsistent with results herein.

From a study in highland country in New South Wales, Driscoll (1977) found that the number of bird species is similar in pine plantations of varying ages but is less than in native forests.

Friend (1982) found, in a study of bird populations in exotic pine plantations and eucalypt forests in Gippsland, Victoria, that the highest numbers of birds in dense, middle-aged plots were restricted to the edges. Areas of native forest, dams and clearings within pine plantations added to the diversity of habitats and provided more individuals and species of birds. Ecotonal areas were most important.

The yellow-tailed black-cockatoo is not mentioned in the Results section of this paper lecause it was not seen in the pine plots during this study, although there was clear evidence that this species had torn open dead pines, both standing and 1ying, in four of the plots.

The number of species of birds in each of the pine plots was similar, except for Plot 1 which had a greater number - possibly because of the increased undergrowth. Similarly, there was a like number of species in each of the native forest plots. There was little variation in the number of bird species found in the younger plantations of pines, whether thinned or unthinned. 
One aspect of this study differs from studies in other States. I found only one nest in pine plantations, that of a White's thrush, whereas other studies referred to above have indicated that a number of species nest in pines regularly.

\section{BIRD ECOLOGY OF PINE PLOTS}

Insectivorous species found feeding mostly on the trunks and foliage of the pines were the grey shrike-thrush, brown and Tasmanian thornbills and silvereyes, while those feeding on the ground litter included White's thrush, blackbird, all four robins and the white-browed scrubwren. The last-named and the superb fairy-wren were observed only in the undergrowth, where any occurred, but not in soft tree-ferns. The Tasmanian thornbi11 a1so fed in the undergrowth but not exclusively.

White's thrush was seen in five of the six pine plots and was found nesting in one. Except in Plot 3 they were not seen frequently but I believe they were residents although difficult to see because of their cryptic colouration and secretive nature. In P1ot 1 where I did not record them in the pines, a pair were seen in the native forest nearby and it is likely that they were also in the pines which had extensive ground cover for them.

Plot 4, although almost as old as P1ot 1, had only been first-thinned so that less daylight penetrated and there was much less undergrowth. As a result the superb fairywren was seen much less frequently here and on only one visit were the blackbird and Tasmanian thornbill observed in the undergrowth.

Nectar-feeding birds, such as honeyeaters, were absent, presumably because of the lack of blossoms. Honeyeaters to some extent eat insects also but it is assumed on $1 y$ those normally associated with nectar. The only honeyeater recorded in the pines was an eastern spinebill on a blackberry bush.

Forest ravens were seen in all plots, mostly in the tops of trees and believed to be passing through but sometimes foraging in the ground litter. They were excluded from my counts unless believed to be feeding.

Green rosellas extracted seeds from pine cones on the trees but not from those on the ground. Brush bronzewings may feed on fallen seeds though only once was this species seen in the pines during this survey.

Only one ow1 was recorded: a southern boobook was heard calling in P1ot 1 at 0600 hours on 18 March 1982.

On one occasion three species were seen to fly in to Plot 5 from adjacent pasture seeking shelter from a heavy rainsquall accompanied by high winds. These three were seen in the plot on only one other visit.

The interstate migrants - silvereye, grey fantail, fan-tailed cuckoo, shining bronze-cuckoo and black-faced cuckoo-shrike - were absent during late autumn and winter. There was also a local migration in autumn and winter which brought some species into the pines - scrubtit, pink robin and dusky robin - and others into the native forests only grey butcherbird, strong-billed honeyeater, crescent honeyeater and grey currawong. Scrubtits fed in the pines at heights of 3-6 $\mathrm{m}$ in Plot 6 , but only in undergrowth in Plot 1 .

\section{CONCLUSIONS}

The often-quoted opinion that pine plantations are "biological deserts" is unfounded, but this study showed that the avifauna in pines is restricted to insectivores which forage for insects in the pines and the pine needle litter on the ground, and to a lesser extent to seed eaters. Many insectivores do not find their food in this habitat. 
There was a greater number of bird species in Tasmanian native forests than in pine plantations, and in the latter the number appeared to increase with the amount of undergrowth. Plantations between ten and twenty-five years old, with closed canopies and virtually no undergrowth, appeared least attractive to birds.

To maintain the greatest possible number of bird species it is important that pine plantations should be composed of small plots of varying ages and that these be interspersed with plots of native forest to provide adequate reservoirs of birds and adequate nesting sites. Several bird species require hollows in trees for nesting sites; these are not available in pines, and only in native trees of considerable age (say, over fifty years). Native forest plots should be at least ten hectares in area.

\section{ACKNOWLEDGEMENTS}

This study was financed by the Forest Ecology Research Fund established by the Forestry Commission, Tasmania, and forest-based industries.

My thanks for their support and cooperation in this project go to the staffs of the Forestry Commission at Hobart, Burnie and Scottsdale, and to Dr D. de Little of Associated Forest Holdings at Ridgley.

Dr R. Donaghey reviewed the manuscript and I am most grateful for his advice.

\section{REFERENCES}

Cowley, R.D., 1971: Birds and forest management. Aust. For., 35: 234-250.

d'Andria, A., 1968: Bixdlife in a Canberra pinewood. Canberra Bird Notes, 2: 2-5. Davidson, P.M., 1976: Birds in pine forests. Studies in Forest Enviroment No.1., Dept of $A . C . T$.

Disney, H.J.des. \& Stokes, A., 1976: Birds in pine and native forests. Emu, 76: 133-138. Driscoll, P.V., 1977: Comparison of bird counts from pine forests and indigenous vegetation. Aust. Wildz. Res., 4: 281-288.

Fielding, P., 1976: Birds in pine plantations in Tasmania. Tasm. Nat., 45: 5-8. Friend, G.R., 1982: Bird populations in exotic pine plantations and indigenous eucalypt forests in Gippsland, Victoria. Emu, 82: 80-91.

Gepp, B.C., 1976: Bird species distribution and habitat diversity in an exotic forest in South Australia. Aust. For., 39: 269-287. \& Fife, A.J., 1975: Birds seen in forest reserves in South Australia. S. Aust. Orn., 27: 12-17.

Kloeden, J.I., 1973: Rine plantations. Wilalife in Aust., 10: 130-133.

Pawsey, C.K., 1966: Birds in relation to pine forests of the south-east of South Australia. S. Aust. Om., 24: 93-95.

Ratkowsky, A.V. \& Ratkowsky, D.A., 1978: A survey of the birds of the Mt Welliliton Range, Tasmania, during the non-breeding months. Emu, 78: 223-226. - 1980: A survey of the birds of two areas of sclerophyl1 bushland in southern Tasmania. Emu, 80: 169-170.

Ridpath, M.G. \& Moreau, R.E., 1966: The birds of Tasmania: ecology and evolution. Ibis, 108: 348-393.

Suckling, G.C., Backen, E., Heislers, A. \& Neumann, F.G., 1976: The fauna and flora of radiata pine plantations in north-eastern Viatoria. For. Comm. Victoria Bulz. No.24. 